\title{
RELATIONAL ANALYSIS OF PHYSICAL FACILITIES IN GOVERNMENT SCHOOLS AND THEIR IMPACTS ON STUDENTS' ACADEMIC ACHIEVEMENTS AND BEHAVIORAL DEVELOPMENT IN MALAKAND DIVISION
}

By

\author{
Dr. Arab Naz ${ }^{1}$, \\ Waseem Khan ${ }^{2}$, \\ Nasim Khan ${ }^{3}$
}

\begin{abstract}
Physical infrastructure plays a pivotal role in performance of students in academics as well as co-curricular performance. The study is framed to investigate students' academic performance in relation to the available physical facilities in Malakand division of Khyber Pakhtunkhwa Pakistan. The data has been obtained from secondary and field sources related to the issue of building and class size, quality of physical facilities as well as their impacts on test scores, grades, class participation etc. The field information is obtained from 300 samples of four selected boys' high schools through stratified sampling technique using interview schedule. The field data was finally classified in the form of tables, and given frequency with respect to various observations with detailed discussion at the end. The information thus concludes that physical infrastructural facilities highly influence students' academic performance and personality development.
\end{abstract}

Key words: Physical facilities, grades, score, class, building, academic achievement etc.

\footnotetext{
${ }^{1}$ Chairman Department of Sociology and Social Work, University of Malakand Khyber Pakhtunkhwa Pakistan

${ }^{2}$ Lecturer and PhD scholar, Department of Sociology and Social Work, University of Malakand Khyber Pakhtunkhwa Pakistan

${ }^{3}$ Lecturer Department of Sociology AIOU Islamabad Pakistan
} 


\section{Study Background}

Physical infrastructure is pivotal for any educational institution and is directly associated with performance of students in academics as well as in co-curricular development (McGuffey's, 1982). Similarly, a close and constant link between building availability and tests scores among students has been observed by Earthman \& Lemasters, (1998) while Plumley (1978) and Chan (1979) are of the opinion that physical facilities improve basic skills and higher grade across a range of tests. Research studies show that students in facilitated infrastructure in school perform well for health, attendance, and discipline (Bowers \& Burkett, 1987) and even in behavior and achievements in personality as well (Phillips, 1997 and Jago \& Tanner, 1999). Further, the available design, mapping and topography is also important as noted by Andersen (1999) whereas Lewis (2000) has judged the effects of such qualities over students learning and skill development and has found positive outputs.

Another important aspect of such facilities is personality organization where Earthman et al. (1995) argue that structural differences are the indicators in quality education and behavioral formation. Besides, the comfortable physical environment as noted by Coopers (2001) is playing an important role in teachers' motivation, school leadership, and students learning (Henderson \& Raywid, 1994). However, research scholars have linked the availability of school and its size to cultural environment (Howley, Strange, \& Bickel, 1999) and even to the government policies (Cotton, 1996 \& 2001) because in both the cases whether large or small, valuable results are available. Further, many of the scholars treated school as an ecological environment for behavior formation and large size are considered as signs of power and rightness (Barker \& Gump, 1964).

Similarly, many scholars have pointed towards the positive outcomes of school size as noted by Wasley et al. (2000) that small size improves education through intimate learning communities while Schneider et al, (2000) and Nathan \& Febey (2001) add that small schools encourage parental involvement that facilitate both teachers and students. Besides, school size has advantages and disadvantages as Raywid (1999) favors small size of the schools for students' satisfaction and to reduce dropout ratio while Fowler \& Walberg (1991) and Lee \& Smith, (1997) and Keller, (2000) found that higher test scores are linked with school size.

The school size and other infrastructural components are also effective in students sociopsychological and personality development i.e. small size schools can reduce violence, aggression and disruptive behavior as stated by Gregory (1992), Stockard \& Mayberry (1992) and Kershaw \& Blank (1993). Further, school size can improve students' attitudes, behavior and social conformity and produces "we feeling” (Barker \& Gump, 1964). Further, school size can enhance students' participation in school activities, their satisfaction, attendance, and feeling of belongingness (Fowler \& Walberg, 1991 and Stockard \& Mayberry 1992) and to Toenjes (1989) it is playing a pivotal role in reducing drop-out as well as increases higher graduation ratio with positive attitude towards academic performance (Pittman \& Haughwout 1987, Gottfredson 1985, Stockard \& Mayberry 1992, Lee \& Loeb, 2000). In a similar context, school infrastructure and physical facilities along-with proper size of class room is very much important in students' academics i.e. large or small size has its own benefits to enhance the academic performance (National Association of Elementary School Principals, 2000, Hanushek, 1999). Similarly, using a range of data have found that reducing class size has no effect on educational outcomes as noted by Hoxby (2000) while analysis of the relationship between class size and students' achievement, Johnson (2000) finds no effect of class size on reading scores, other things being equal while Mosteller (1995) and Slavin (1989) find effects only for very large declines in class size. However, Ferguson (1991) is of the view that a significant relationship among teacher 
quality, class size, and student achievement exists and such argument is also supported by Folger \& Breda (1989) and, Ferguson \& Ladd (1996). Thus, it can concluded that school infrastructure, availability and size of buildings, quality and size of schools, class room and class rooms' size have multiple positive impacts on students’ academic performance and achievement.

\section{Objectives of the Study}

1. To analyze how students perceive school size as an indicator in their academic achievement

2. To know about the impacts of physical facilities in students’ personality and behavioral modification

3.

\section{Proposed Hypothesis}

1. Availability of better infrastructural facilities are directly concerned with students' academic achievement

2. Better availability of physical and infrastructural facilities elegantly develop students' behaviors and bring lucrative changes in their personality

\section{Methods and Material}

The current study is about the analysis of the available school buildings, rooms, play grounds and other such physical facilities and their impacts on students' academic performance, behavioral and personality development in Malakand division of Khyber Pakhtunkhwa Pakistan. A pure quantitative design has been adopted for empirical data on student's educational and behavioral performance in relation to physical infrastructure. The field data is obtained from 300 samples of four selected boys' high schools coded as Government High School Number-1 GHS1, GHS-2, GHS-3, and GHS-4, from two selected towns of Thana and Batkhela through stratified sampling technique by using interview schedule. The collected information was finally classified and coded with the specific observations, distributed into frequencies in tables alongwith discussion in various dimensions of the study.

\section{Results and Discussion}

\section{Physical facilities and Students’ Academic Performance}

The perception of human being is usually based on model of the world and their demonstrated utility as stated by Smith et al, (2003) while students' perceive the utility of school size as an indicator for achieved academic performance. The field data shows that physical facilities have multiple impacts on students' academic performance and the statistical enumeration explicates that class participation and other class related activities have been promoted due to physical facilities and the statement is supported by a majority of $73 \%$ students to a greater extent while $82 \%$ of the sample data reflects that physical facilities at school enhances students' confidence level to a major extent. Besides, the information from the field data indicate the availability of physical facilities increases students' learning and motivation for class participation i.e. 84\% of the sample support the statement to a greater extent whereas $83 \%$ data analyzed in the table clearly shows that better grades are result of physical facilities. Similarly, achieving better results and improving students' creativity (i.e. supported by $87 \%$ of the data to a greater extent) and promoting students' participation in co-curricular activities i.e. 
85\% student support the statement to a greater extent are directly associated with the available physical or infrastructural facilities available to students in schools (see Table-1).

Table-1

Physical Facilities and Nature of Academic Performance (Cross Tabulation, Sample Size, $\mathrm{N}=300$ )

\begin{tabular}{|c|c|c|}
\hline \multirow{2}{*}{ Nature of Performance } & \multicolumn{2}{|c|}{ Level and Extent of Performance } \\
\hline & To Some Extent & To Greater Extent \\
\hline Increase in Class Work and Activities & $27 \%$ & $73 \%$ \\
\hline Promoting level of Confidence & $18 \%$ & $82 \%$ \\
\hline Increase in Class Attendance & $21 \%$ & $79 \%$ \\
\hline Increase in Students Learning and Motivation & $16 \%$ & $84 \%$ \\
\hline Performance in Grade Achievement & $17 \%$ & $83 \%$ \\
\hline Achieving Better Results and Students’ Creativity & $17 \%$ & $87 \%$ \\
\hline Promoting Participation in C-Curricular activities & $15 \%$ & $85 \%$ \\
\hline
\end{tabular}

Resultantly, the test statistics obtained for physical facilities and students' academic performance with the application of chi-square test with the results as $\mathrm{P}=.000^{* *}<.05$ shows highly significant relationship at $\left(\chi^{2}=76.93\right.$, D.f. $\left.=9\right)$ whereas the correlation for the association is given as under:

\section{Correlation of physical facilities and Students Academic Performance}

\begin{tabular}{llrr}
\hline & & $\begin{array}{c}\text { Performance/areas } \\
\text { that is affected }\end{array}$ & \multicolumn{2}{c}{$\begin{array}{c}\text { Data regarding physical } \\
\text { facilities available }\end{array}$} \\
Nature of Academic & Pearson Correlation & 1 & $0.934^{\star *}$ \\
aspects & Sig. (2-tailed) & 300 & .000 \\
& $\mathrm{~N}$ & $.932^{* *}$ & 300 \\
Physical facilities & Pearson Correlation & .000 & 1 \\
available & Sig. (2-tailed) & 300 & 300 \\
& $\mathrm{~N}$ & 300 \\
\hline
\end{tabular}

$\left({ }^{* *}\right.$ The given value of Correlation is highly significant where the judgment is 0.01 level (2-tailed), $\mathrm{r}(300)=0.934^{* *}$; $\left.\mathrm{p}<.01 . \mathrm{r}^{2}=0.91\right)$ and the sharing is $87 \%$ of the variance which demonstrate strong association

The results of the correlation as given ${ }^{* *}$ Correlation is significant at the 0.01 level (2tailed), $r(300)=0.932^{* *} ; \mathrm{p}<.01 . \mathrm{r}^{2}=0.91$, while $87 \%$ of the variance is shared which is obviously showing a strong association for the given variables.

\section{Physical Facilities, Students Personality and Behavioral Development}

Behavior of a person refers to his/her that is prevalent to change the relationship to the observed environment for producing actions and mannerism (Dusenbery, 2009). Similarly, educational institutions are pivotal in molding the behavior and personality of the individual through learning instruments and available social and physical infrastructure. The analysis with respect to the personality and behavior output illustrates that physical facilities are pivotal in behavioral development and personality formation of the students. The data analyzed in table- 2 indicate that availability of physical facilities to students encourage positive attitudes and high 
self-esteem among students in the academic institutions and the notion was supported to a greater extent by $83 \%$ of the sample population, which indirectly influences students' behavioral capacity and personality. The statistical interpretation of the data further demonstrates that availability of physical facilities increases positive social relations among students in school i.e. $87 \%$ of the students support the students to a greater level while $82 \%$ of the respondents were of the opinion that such facilities have a positive role in reducing aggression in behavioral aspects of the students to a greater extent. Further, the empirical data reflects that physical facilities develop friendly atmosphere among students and such statement has been supported by a majority of $86 \%$ of the respondents to a greater extent whereas such atmosphere bring emotional stability was supported by $79 \%$ of the sample population to a greater extent. Similarly, infrastructural components in educational institutions directly influences the personality and behavior of the students as the tabulated data in this context clearly demonstrate that physical facilities available to students at school provide conducive environment to bring compromising attitude among students as $81 \%$ of the students support the notion to a greater extent. Further, love and affection for fellow-beings was agreed upon by $82 \%$ of the students to greater extent, reduction of frustration, anxiety and tension was supported by $78 \%$ while the encouragement of absorption and flexibility in behavior of students was supported by $77 \%$ of the sample data to greater extent. Thus, the information illustrate that physical facilities have a positive relations with students behavior and personality development (see table-2 below):

Table-2

\section{Physical Facilities, Students Behavioral and personality growth} (Cross Tabulation, Sample Size, $\mathrm{N}=300$ )

\begin{tabular}{|c|c|c|}
\hline & To Some Extent & To Greater Extent \\
\hline Formation of positive and high Self-Esteem & $17 \%$ & $83 \%$ \\
\hline Increase positivity in social relations & $13 \%$ & $87 \%$ \\
\hline Decrease in behavioral Aggressiveness & $18 \%$ & $82 \%$ \\
\hline Encourage friendly Relations & $14 \%$ & $86 \%$ \\
\hline Develop Emotional Stability & $21 \%$ & $79 \%$ \\
\hline Bringing Comprising attitudes & $19 \%$ & $81 \%$ \\
\hline Encourage love and affection for fellow being & $18 \%$ & $82 \%$ \\
\hline Reduces Frustration, tension and anxiety & $22 \%$ & $78 \%$ \\
\hline Encourage Absorption and Flexibility in behavior & $23 \%$ & $77 \%$ \\
\hline
\end{tabular}

Note: $\left(\mathrm{P}=.000^{* *}<.05\right.$ and found a highly significant relationship between Physical Facilities, Behavioral and personality development with the value of $\chi 2=66.89$, D.f. $=8$

The application of the test statistics on the hypothetical statements was tested through the application of chi-square test whereas the value of $\mathrm{P}=.000^{* *}<.05$ that shows a significant relationship regarding the positive outcome of infrastructural facilities with obtained values as $\chi^{2}$ $=66.89$, D.f. $=8$. Similarly, the associations of the given aspects were analyzed through correlation as given in the following table:

\section{Correlation for Students Behavioral and personality Development}

\begin{tabular}{llrr}
\hline & & $\begin{array}{c}\text { Physical and } \\
\text { infrastructural } \\
\text { components }\end{array}$ & \multicolumn{2}{c}{$\begin{array}{c}\text { Personality and Behavioral } \\
\text { Development }\end{array}$} \\
$\begin{array}{l}\text { Physical and } \\
\text { infrastructural }\end{array}$ & $\begin{array}{l}\text { Pearson Correlation } \\
\text { Sig. (2-tailed) }\end{array}$ & 1 & $0.947^{\star *}$ \\
& & & .000
\end{tabular}




\begin{tabular}{|c|c|c|c|}
\hline components & $\mathrm{N}$ & 300 & 300 \\
\hline Personality and & Pearson Correlation & $.947^{\star \star}$ & 1 \\
\hline Behavioral & Sig. (2-tailed) & .000 & \\
\hline Development & $\mathrm{N}$ & 300 & 300 \\
\hline
\end{tabular}

With the given tabulated information, the statistical results of the various test and correlation illustrates that the given results i.e. ${ }^{* *}$ Correlation is highly significant at the 0.01 level (2-tailed), $r(300)=0.947^{* *} ; \mathrm{p}<.01 . \mathrm{r}^{2}=0.91$ and the sharing of $83 \%$ of the variance indicate that the association is obviously a strong in nature and further, results of chi-square application prove that random and non-random variables and strongly linked with one another.

\section{Conclusion}

It is obvious that physical and infrastructural facilities are playing an important role in development of education and enhancement of students academics, behavior and personality formation. The analyses of the secondary information illustrate a consensus about the positive effects of physical and infrastructural facilities on students' performance at various levels. However, in support of the given argument, the empirical analyses also indicate that availability of physical and infrastructural components in education have greater positive impacts on students' overall performance. Such facilities enhance students' participation during class, increases attendance of the students, enhance students learning capacity as well as remove negativity in behavior of students for one another. Similarly, physical and infrastructural components have positive role in motivation of students, performance and grade achievement, producing better results in examination as well as promotion of co-curricular activities as well. Similarly, in relation to improve the behavioral and personality aspects students, the study findings express that physical and infrastructural facilities increase positivity in students behavior, create a sense of love and affection, promote positive self-esteem, reduces behavioral aggression, develop emotional stability, encourage compromising behavior, reduce frustration, anxiety and tension, and further enhances the capacity to absorb and bring flexibility in behavior and personality of the students. In the nutshell, students' academic, behavioral and personality outcome are dependent upon school physical as well infrastructural environment.

\section{Recommendations}

In order to improve the academic performance of the students and bring positive changes in behavior and personality of the students, the following are recommended:

1. Seating arrangement shall be made proper and according to the school and room size, students shall be provided with space.

2. There should be better transport and communication facilities for the students to improve their capacities and capabilities.

3. The administration should provide chairs, clean water, and politics-free environment to improve the behavioral and academic performance as well as personality of the students.

4. Time management for recreational and leisure activities shall be properly utilized and also the existing playground(s) must be made functional for such purposes. 


\section{REFERENCES}

Andersen, S. 1999. The relationship between school design variables and scores on the Iowa Test of Basic Skills. Athens, Ga.: University of Georgia.

Angler, B. 2009. Personality Theories: Eighth Edition. Belmont, CA: Wadsworth, Cenage Learning.

Barker, R. G., and P. V. Gump. 1964. Big school, small school: High school size and student behavior. Stanford, Calif.: Stanford University Press. (ED001132).

Bates, J. 1996.Healthy learning. American School \& University 68(5), pp. 27-29.

Bowers, J. H., and C. W. Burkett. 1987. Relationship of student achievement and characteristics in two selected school facility environmental settings. Paper presented at the 64th Annual International Conference of the Council 18 Do School Facilities Affect Academic Outcomes?

Chan, T. 1979. The impact of school building age on pupil achievement. Greenville, S.C.: Office of School Facilities Planning, Greenville School District. (ED191138)

Coopers. P. 2001.Building performance: An empirical analysis of the relationship between schools' capital investment and pupil performance. United Kingdom: Department for Education and Employment.

Cotton, K. 1996. School size, school climate, and student performance. Portland, Ore.: Northwest Regional Educational Laboratory. Retrieved 07/03/02 from http://www.nwrel.org/scpd/sirs/10/c020.html

Cotton, K. 2001. New small learning communities: Findings from recent research. Portland, Ore.: Northwest Regional Educational Laboratory. Retrieved 07/03/02 from http://www.nwrel.org/scpd/sirs/nslc.pdf

Dusenbery, D. B. 2009. Living at Micro Scale, p. 124. Harvard University Press, Cambridge, Mass. ISBN 9780-674-03116-6.

Earthman, G. I., and L. Lemasters. 1998. Where children learn: A discussion of how a facility affects learning. Paper presented at the annual meeting of Virginia Educational Facility Planners. Blacksburg, Va., February. (ED419368)

Earthman, G. I., C. Cash, and D. Van Berkum. 1995. A statewide study of student achievement and behavior and school building conditions. Paper presented at the annual meeting of the Council of Education Facility. Do School Facilities Affect Academic Outcomes?

Farber, P. 1998. Small schools work best for disadvantaged students. Harvard Education Letter (March/April).

Ferguson, R. F. 1991. Paying for public education: New evidence on how and why money matters. Harvard Journal on Legislation 28 (2): 465-98.

Ferguson, R. F. and H. Ladd. 1996. Additional evidence on how and why money matters: A production function analysis of Alabama schools. In Holding Schools Accountable: Performance-Based Reform in Education, ed. Helen F. Ladd. Washington, D.C.: The Brookings Institution.

Folger, J., and C. Breda. 1989. Evidence from project STAR about class size and student-achievement. Peabody Journal of Education 67 (1): 17-33. 
Fowler, W. J., Jr. 1995.School size and student outcomes. In Advances in Educational Productivity, vol. 5, ed. H. J. Walberg. Greenwich: Conn. JAI Press, Inc., pp. 3-26.

Fowler, W. J., Jr., and H. J. Walberg. 1991. School size, characteristics, and outcomes. Educational Evaluation and Policy Analysis 13 (2): 189-202.

Gottfredson, D. C. 1985. School size and school disorder. Baltimore, Md.: Center for Social Organization of Schools, Johns Hopkins University. (ED261456)

Greenwald, R., L. V. Hedges, and R. D. Laine. 1996. The effect of school resources on student achievement. Review of Educational Research 66 (3): 361-96.

Gregory, T. 1992. Small is too big: Achieving a critical anti-mass in the high school. Position paper prepared for the Hubert H. Humphrey Institute for Public Affairs and the North Central Regional Educational

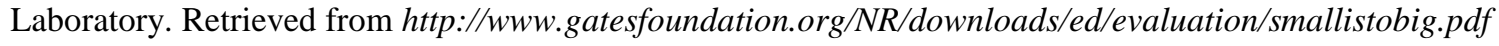

Hanushek, E. A. 1997. Assessing the effects of school resources on student performance: An update. Educational Evaluation and Policy Analysis 19 (2): 141-64.

Hanushek, E. A. 1999. Some findings from an independent investigation of the Tennessee STAR experiment 20 Do School Facilities Affect Academic Outcomes? National Clearinghouse for Educational Facilities 1090 Vermont Avenue, N.W., Suite 700, Washington, D.C. 20005-4905 888-552-0624 www.edfacilities.org (C2002, National Institute of Building Sciences and from other investigations of class size effects. Educational Evaluation and Policy Analysis 21 (2): 143-63.

Henderson, H., and M. A. Raywid. 1994. "Small” revolution in New York City. Journal of Negro Education 63 (1): 28-45.

Hord, S. M. 1997. Professional learning communities: What are they and why are they important? Southwest Educational Development Laboratory, Issues about Change 6 (1): 1-9. Retrieved on 07/19/02 from http://www.sedl.org/change/issues/issues61.html

Howley, C. 1994. The academic effectiveness of small scale schooling (an update). ERIC digest. Charleston, W. Va.: ERIC Clearinghouse on Rural Education and Small Schools. Retrieved on 07/19/02 from http://www.ed.gov/databases/ERIC_Digests/ed372897.html

Howley, C. B. 1995. The Matthew principle: A West Virginia replication? Education Policy Analysis Archives. 3 (18): $1-25$.

Howley, C. B., and R. Bickel. 1999. The Matthew project: National report. Randolph, Vt.: Rural Challenge Policy Program.

Howley, C., M. Strange, and R. Bickel. 2000. Research about school size and school performance in impoverished communities. ERIC digest. Charleston, W. Va.: ERIC Clearinghouse on Rural Education and Small Schools. Retrieved 07/19/02 from http://www.ael.org/eric/digests/edorc0010.htm

Hoxby, C. M. 2000. The effects of class size on student achievement: New evidence from population variation. The Quarterly Journal of Economics 115 (3): 1239-84.

Hunt, M. 1997. How science takes stock: The story of meta-analysis. N.Y.: Russell Sage Foundation. 
Jago, E., and K. Tanner. 1999. Influence of the school facility on student achievement: Lighting; color. Athens, Ga.: Dept. of Educational Leadership; University of Georgia. Retrieved 07/22/02 from http://www.coe.uga.edu/sdpl/researchabstracts/visual.html

Johnson, K. A. 2000. Do small classes influence academic achievement? What the national assessment of educational progress shows. Washington, D.C.: Heritage Foundation. Retrieved 07/23/02 fromhttp://www.heritage.org/Research/Education/CDA00-07.cfm

Keller, B. 2000. Small schools found to cut price of poverty. Education Week 19 (22): 6. Retrieved 07/22/02 from http://www.edweek.com/ew/ewstory.cfm?slug=22size.h19

Kershaw, C. A., and M. A. Blank. 1993. Student and educator perceptions of the impact of an alternative school structure. Paper presented at the annual meeting of the American Educational Research Association,

Lee, V. E., and J. B. Smith. 1997. High school size: which works best and for whom.Educational Evaluation and Policy Analysis 19 (3): 205-27.

Lee, V. E., and S. Loeb. 2000. School size in Chicago elementary schools: Effects on teachers' attitudes and students' achievement. American Educational Research Journal 37 (1): 31.

Lewis, M. 2000. Where children learn: Facilities conditions and student test performance in Milwaukee public schools. Scottsdale, Ariz.: Council of Educational Facility Planners International. Retrieved 07/22/02 from http://www.cefpi.org/pdf/issue12.pdf

Lowe, J. M. 1990. The interface between educational facilities and learning climate in three elementary schools. Ph.D. diss. College Station, Tex.: Texas A\&M University.

Lucas, J. 1981. Effects of noise on academic achievement and classroom behavior. Sacramento, Calif.: California Department of Health Services.

McGovern, M. A. 1998. A breath of fresh air.School Planning and Management 37 (10): 14.

McGuffey, C. 1982. Facilities. In Improving educational standards and productivity: The research basis for policy, ed. H. Walberg. Berkeley, Calif.: McCutchan Pub. Corp.

Mosteller, F. 1995. The Tennessee study of class size in the early grades.The Future of Children 5 (2): 113-27.

Nathan, J., and K. Febey. 2001. Smaller, safer, saner, successful schools. Washington, D.C.: National Clearinghouse for Educational Facilities and Minneapolis, Minn.: Center for School Change, Humphrey Institute of the University of Minnesota. Retrieved 07/03/02 from http://www.edfacilities.org/pubs/saneschools.pdf

National Association of Elementary School Principals. 2000. Does size really matter? The debate over class size. Alexandria, Va.: National Association of Elementary School Principals. Retrieved 07/03/02 from http://www.naesp.org/comm/c1200.htm

Naz, A., Khan, W., Rehman, H., and Khan, T. (2011). The Dilemma of Women's Education in Pakistan: An Investigation into the Various Socio-Religious and Political Constraints in Women's Educational Empowerment in Pakhtoon Society of Khyber Pakhtunkhwa Pakistan. Accepted in Indian Journal Of Health And Wellbeing In September issue. ISSN.2229-5356.

Phillips, R. 1997. Educational facility age and the academic achievement of upper elementary school students. D. Ed. diss., University of Georgia. 
Pittman, R. B., and P. Haughwout. 1987. Influence of high school size on dropout rate. Educational Evaluation and Policy Analysis 9 (4): 337-43.

Plumley, J. P. 1978. The impact of school building age on the academic achievements of selected fourth grade pupils in the State of Georgia. Athens, Ga.: University of Georgia.

Raywid, M. A. 1999. Current literature on small schools. ERIC digest. Charleston, W. Va.: ERIC Clearinghouse on Rural Education and Small Schools. Retrieved 07/22/02 from http://www.ael.org/eric/digests/edorc988.htm

Santrock, John W. 2002. A topical approach life-span development (illustrated ed.), McGraw-Hill, ISBN978-007-243599-3, http://books.google.com/?id=-MYyNgIyXUAC.

Schneider, M., P. Teske, and M. Marschall. 2000. Choosing schools. Princeton, N.J.: Princeton University Press.

Slavin, R. 1989. Achievement effects of substantial reductions in class size. In School and classroom organization, ed., R. Slavin. Hillside, N.J.: Erlbaum.

Smith, E. E., Nolen-HOedsema, S., Fredrickson, B. L., and Loftus, G. R. (2003).Introduction to Psychology $\left(14^{\text {th }}\right.$ Ed). Thomson Wadsworth Inc.

Stockard, J., and M. Mayberry. 1992. Resources and school and classroom size. In effective educational environments. Newbury Park, Calif.: Corwin Press, Inc.

Toenjes, L. A. 1989. Dropout rates in Texas school districts: influences of school size and ethnic group. Austin, Tex.: Texas Center for Educational Research.

Walberg, H. J. 1992. On local control: Is bigger better? In Source book on school and district size, cost, and quality. Minneapolis, Minn.: Minnesota University, Hubert.

Wasley, P. M., M. Fine, N.E. Gladden, S. P Holland, E. King, E. Mosak, and L. C. Powell. 2000. Small schools: Great Strides. A study of new small schools in Chicago.Retrieved 07/03/02 from http://www.bnkst.edu/html/news/SmallSchools.pdf. 